\title{
Discrepancy between the Theory and Practice of Crime Prevention
}

\author{
IGOR' M. MATSKEVICH \\ Kutafin Moscow State Law University, Moscow, Russian Federation \\ Lomonosov Moscow State University, Moscow, Russian Federation \\ ORCID: https://orcid.org/0000-0002-4270-1599, e-mail: mackevich2004@mail.ru
}

\begin{abstract}
Introduction: the article considers the concept of prevention in several aspects (social prevention, criminological prevention, situational prevention, evolutionary prevention). Aim: describe the subjects implementing the prevention of offenses and consider the issue of public participation in this process in historical and modern periods. We focus our attention on the prevention of new crimes in the institutions of the Federal Penitentiary Service, emphasize its importance during the period of serving a sentence (educational techniques and methods) and after release (interaction of probation inspectorates with law enforcement agencies for the re-socialization of released convicts). We outline possible risks and difficulties of organizing crime prevention together with public organizations: determining preferences for activists; politicization of preventive work (obtaining additional electoral points); selection of activists (preventing the involvement of representatives of the criminal environment). In the context of considering ways to improve prevention, much attention is paid to the prevention of crime through technological innovations: control over people's movement using a mobile phone; analysis of web browsing history; computer programs for crime prevention; compilation and maintenance of federal database programs; chipping, etc. The study is based on the accumulated experience of implementing preventive work, which is described in the sections "Prevention yesterday" and "Prevention today". The article analyzes examples of crime prevention in Thailand, the U.S. etc., and reflects the results of implementation of the "Safe City" program in Moscow. The methodological basis of this study is represented by the axiological approach. Research problems were addressed with the use of general philosophical principles of dialectics and special methods of cognition: systematic, formal-legal, sociological, etc. Results: the public remains the most important element of the prevention system. It is necessary to develop and legally consolidate the relevant activities, for example, as it is done in Article 11 of the Federal Law "On the fundamentals of the system for prevention of neglect and juvenile delinquency". Legal education should be the main weapon in the hands of the subjects of prevention. Elimination of crime should become the main direction of prevention.

Keywords: prevention; crime prevention; public participation in prevention; centralization/decentralization of prevention; criminogenic domestic zones; technological innovations in crime prevention; re-socialization; legal education.
\end{abstract}

12.00.08 - Criminal law and criminology; penal law.

For citation: Matskevich I.M. Discrepancy between the theory and practice of crime prevention. Penitentiary Science, 2021, vol. 15, no. 3 (55), pp. 605-612. DOI 10.46741/2686-9764-2021-15-3-605-612.

\section{Definition of prevention}

Science contains several concepts of prevention. We will focus on some of them, since they are of interest in relation to the problem declared in the title of this article.

Social prevention includes a wide range of measures aimed to address the causes and conditions of not only crimes and offenses, but also all social pathologies, various forms and types of deviant conduct, or as it is now fashionable to say, maladaptive conduct, including alcoholism, drunkenness, vagrancy, sexual and social promiscuity and other antisocial conduct that violates not only and not so much legal, but 
moral, religious and ethical rules of human behavior in society [1, p. 13].

Prevention of offenses is the impact on the causes and conditions of both criminally punishable socially dangerous acts and other legal torts that are forms of misconduct: administrative offenses, disciplinary offenses, civil law offenses, procedural offenses [1, p. 12].

Criminological prevention is the prevention of crimes, plus the prevention of certain noncriminal offenses, primarily administrative offenses, which are closest in their objective side to the composition of a particular crime [1, p. 13].

Based on these definitions, we can identify several key elements that make up the subject of prevention. These are: a) identification of the causes and conditions of social pathologies; b) development of forms and methods for eliminating these causes and conditions; c) continuous measurements of the degree of public health (maybe even public ill health, i.e. diseases of society or any part of it, for example, a specific region in the country or a relatively large social group); d) analysis of the emergence of new pathologies; e) monitoring the quality of the law enforcement system; e) inclusion of the public in preventive work.

\section{Situational prevention}

We understand situational crime prevention as various options for differentiating preventive activities. Situational prevention is called reformatory, and it is contrasted with evolutionary prevention, which is obviously understood as the state system for crime prevention [8].

Despite its apparent novelty, the term "situational prevention" was introduced into scientific circulation back in 1980. Its author was the UK scientist Ronald V. Clarke. He made his conclusions based on the Home Office data obtained while studying the influence of an indefinite set of factors that lead to the commission of a crime. Ronald V. Clarke concluded that instead of endlessly considering the main typical problems that make people commit crimes, it is necessary to focus on identifying the factors that allow people to commit crimes. These factors that make it possible to commit a crime are easier to identify, mitigate and their negative impact is easier to mitigate. This approach was called situational crime prevention. The idea of Ronald V. Clarke was based on the rational choice theory in economics, which was described, among others, by the American scientist Gary Becker in the late 1960s. In turn, the rational choice theory is based on the hy- pothesis that social behavior patterns proceed from the fact that each person makes decisions based on: a) their own preferences; b) the limitations they face; c) available information; d) reason, not instinct, to guide their actions.

Situational prevention goes beyond the justice system. Criminal law is considered here as part of anti-crisis management efforts and, accordingly, is necessary primarily for analyzing specific types of crimes and understanding why these crimes are committed. After identifying situational factors that contribute to the commission of a crime (types of crimes), intervention methods are developed in order to eliminate them. Thus, situational prevention in theory is aimed at reducing the opportunities for committing crimes rather than punishment and subsequent social rehabilitation of criminals.

There are five main methods of situational prevention: 1) 1) increasing the difficulties (what can be called an increase in the intensity of the use of preventive measures); 2) increasing the risks (an increase in the probability of negative consequences, what Rudolph Giuliani, the Mayor of New York City from 1994 to 2001, called "zero tolerance for crime"); 3) reducing the rewards (exceeding the negative consequences for the offender compared to the benefits of committing illegal actions); 4) reducing opportunities (elimination of conditions for committing crimes, for example, the lack of security on the territory of the warehouse); 5) removing excuses (the inevitability of punishment for the committed illegal action, and it does not necessarily have to be a criminal legal measure, but punishment, for example, serious public censure, must necessarily follow).

Quite widely, situational prevention methods are used to prevent drunk driving. For example, Thai criminologists have proposed: a) to make it more difficult for drunk drivers to drive a car (increasing the difficulties of drunk driving); b) to abolish the liberal practice of police officers against drunk drivers (increasing the risks of drunk driving); c) to raise fines for drunk driving (reducing the rewards of drunk driving); d) to oblige citizens to report to the police if it becomes known that an intoxicated person is trying to drive a car (reducing opportunities for drunk driving); e) to eliminate the possibility of release for drunk driving (removing excuses) [10].

A direct consequence of the dominance of situational crime prevention in modern criminology is the adoption of the "Safe City" con- 
cept, in which one of the main directions is the prevention and detection of offenses through video surveillance systems [8].

Meanwhile, the Soviet and Russian theory of crime prevention has never focused exclusively on factor-based or state approaches. On the contrary, it was distinguished by the complexity and diversity of views, which in turn was provided by dialectical methods of cognition and constantly improving ways for addressing new problems. How far this has been solved in practice is another question.

Therefore, for us, situational crime prevention is not a fresh approach to old problems. However, it would be unreasonable to ignore the experience of other scientists, especially since it certainly has rational grains.

\section{Prevention yesterday}

According to the first and so far the only academic course of domestic criminology, labor collectives, amateur non-governmental organizations and educational organizations, crime prevention councils, squads, community courts and public order protection stations [2, p. 19] play an essential role in the crime prevention system; all these institutions are now united under the title "public prevention".

Without broad public participation in the prevention of offenses, prevention itself loses its original meaning. In the same academic course, it was reasonably argued that relying only on the activities of punitive bodies in crime prevention is based on the false idea that if the state has strict laws, and the courts widely apply punishment, then crime will be done with [2, p. 23].

At the same time, it is important (we will discuss it in more detail a little later) to understand that previously prevention was based on an extremely strict organizational hierarchy of the only official political party that existed - the Communist Party of the Soviet Union. Formally being a public organization, the CPSU was embedded in the political system at the level of the Constitution, so the instructions of the party leaders at different levels were perceived (and were such in essence) as unconditional for execution. Consequently, prevention had strict centralization and strict disciplinary responsibility (public punishments had serious consequences for people in terms of their further career and employment).

Thus, the prevention of offenses had not only a strict structural organization, but was based on the broad participation of the public in this process.

\section{Prevention today}

Today, prevention is decentralized. Of course, in no case can we say that preventive work is not being carried out, but: a) this work is not systematized; b) it is not put at the forefront; c) it is not mandatory.

Currently, Federal Law "On the fundamentals of the prevention system in the Russian Federation" [6] (hereinafter - Federal Law on Prevention) is in force, Article 5 of this law defines the following subjects of the prevention system: 1) federal executive authorities; 2) prosecutor's office; 3) investigative committee; 4) authorities of constituent entities; 5) local government bodies.

We note that the list of subjects is exhaustive. At the same time, it is very unusual that there are no police among the subjects. There are no members of the public either. At the same time, the public is assigned a supporting role as a secondary participant in this work. Article 13 of the Federal Law on Prevention states that public associations exercise their rights in this area through participation in the forms provided for in this law, including participation in relevant state and municipal programs, for example, in the protection of public order and other socially significant events in accordance with the legislation of the Russian Federation.

A significant part of the formulations contained in the legislation on prevention are of a recommendatory nature. For example, Paragraph 30 of the Procedure for keeping records of persons sentenced to correctional labor states that representatives of the public can be (hereinafter - emphasis added. I.M.) involved in educational work and work on the prevention of offenses [4]. Article 158 of the RF Criminal Procedure Code states that an inquirer, the head of an investigative body, an investigator, having established the circumstances that contributed to the commission of a crime, has the right to submit to the relevant organization or the relevant official a presentation about taking measures to eliminate these circumstances or other violations of the law.

Among other things, Article 22 of the Federal Law on Prevention states that a subject authorized in accordance with the legislation of the Russian Federation makes a mandatory submission to the relevant body or organization, regardless of the form of ownership, or a public association, on eliminating the causes and conditions that contribute to the commission of an offense. The subject "does" it rather than "has the right" to do so. 
As it was noted above, public participation in the prevention of offenses is allowed residually, and the major role belongs to state structures. For example, in the case of social adaptation, which is a set of measures aimed at providing people in difficult life situations with the necessary assistance (Article 24 of the Federal Law on Prevention), the public is referred to in the sense that its representatives are involved to provide the necessary assistance.

The fundamental Federal Law "On charitable activities and volunteerism" [3], which is aimed at active participation of the public in the life of society and the state, alas, does not say anything at all about the prevention of offenses.

Meanwhile, people who need help in connection with offenses will turn to the help of state structures last of all. This will happen because: a) offense is an act directed against the state and state structures; b) these persons often consider these structures to be the perpetrators of their own deviations from the law; c) assistance is often provided formally (or rather it is not provided at all); d) even if assistance is provided, it is accompanied by serious restrictions; e) finally, Russian citizens, and this is confirmed by numerous surveys for at least 20 years, to put it mildly, do not fully trust the law enforcement system, i.e., the very subjects of prevention.

At the same time, re-socialization of offenders (Article 25 of the Federal Law on Prevention), i.e. a set of socio-economic and pedagogical measures, cannot be carried out without the participation of the public. Just like social rehabilitation (Article 26 of the Federal Law on Prevention), i.e. a set of measures to restore social ties and functions lost by persons in a difficult life situation, is impossible without the public. This is evident from the content of the measures for re-socialization and rehabilitation, as it is given in the law, and as it really should happen. But not a word has been said about how the public is involved in these processes.

The scope of preventive activities is evidenced by Article 24 of the Federal Law on Prevention, which lists the categories of people in respect of whom such work should be carried out primarily: a) neglected and homeless minors; b) persons serving a non-custodial criminal sentence; c) persons engaged in vagrancy and begging; d) minors subjected to compulsory measures of educational influence; e) persons of no fixed abode; f) other categories of persons, including persons who have undergone treatment for drug addiction, alcoholism and substance abuse, as well as those who are unable to ensure their safety in their own (with their consent).

It is curious that the provision of preventive work in relation to the above-mentioned people should be carried out through: a) stimulating the activities of organizations providing jobs; b) providing social services to persons in need; c) providing state social assistance; d) involving the public.

\section{The public and prevention}

Obviously, the above provisions give rise to more questions than answers in terms of the possibility of their real implementation. In this case, we pay special attention to the fact that the public is of no major importance.

By the way, it is no less surprising that according to the RF Penal Enforcement Code, the public can take part in the reformation of convicts only in one case - when they are serving a sentence in the form of restriction of freedom (Article $47^{1}$ of the RF Penal Enforcement Code). It would seem that in a legal social state, the role and importance of the public should be decisive in helping people who have committed deviations from the norms of the law return to normal life, but the legislator is in no hurry to rely on the help of people united by this goal in this matter.

We cannot say that preventive work is not being carried out, on the contrary, this work is being carried out quite actively in a number of regions. For example, the "Safe City" program has been in action in Moscow for more than 10 years. Moreover, in 2014, an order of the Government of the Russian Federation, approved the Concept for building and developing the hardware and software complex "Safe City" [4], which includes a subsection on law enforcement and crime prevention. But there is still a feeling that this preventive work is far from the existing realities. So, in the abovementioned section of the "Safe City" concept, the emphasis is placed on video surveillance and video recording. Do the developers of the concept seriously believe that they will be able to prevent offenses and crimes only by installing video cameras? Is it not obvious that video cameras are a means and not an end? Prevention is done by hands, not by video cameras. Granted, the possibility of video recording provides significant advantages in the investigation of crimes; but anyway, the crime has already been committed.

\section{Prevention and investigation}

However, prevention does not mean exposure. Moreover, such targeted prevention is 
hard daily work, barely noticeable and, frankly speaking, not very effective. It is difficult to reward a law enforcement officer for prevention, it is much easier to reward them for solving a crime (which also matters). Moreover, prevention is very expensive. To prove this, it is enough to look at the expenses planned to make in Moscow under the program mentioned above. At the same time, we believe that the amount of the allocated funds is unlikely to really meet the needs of prevention (in our opinion, they look quite modest in the program).

The thesis that it is much more efficient to prevent a crime than to investigate it is far from being so unambiguous, despite all its attractiveness. Unfortunately, any (we emphasize any) law enforcement system does not like to engage in prevention: the tasks are unclear, the effectiveness is not obvious, the benefit is questionable, the goal is difficult to achieve.

Is it not the reason why the prevention of offenses and crimes is no longer in high esteem? And does this not relate to the postulate (which has recently been considered almost the ultimate truth) that crime cannot be put an end to, and we can only talk about socially acceptable control over it. In our opinion, this is a very dangerous approach that determines a consumer's attitude toward the very formulation of the problem (is it worth making too much effort if there is nothing to be done anyway, and crime will remain forever?).

Prevention and the Federal Penitentiary Service of Russia

Prevention of new crimes among persons serving a court-imposed sentence is determined by the very content of the work of institutions executing punishments. As a matter of fact, the activity of these institutions consists in the prevention of new crimes that can be committed by convicted persons. But here we mean preventing persons from committing new crimes primarily outside correctional institutions, since their isolation from society is ensured. As for the prevention of crimes by convicts in correctional institutions, then in this case, as we know, everything is not so clear.

In fact, preventive activity in FSIN institutions is determined by the very fact of its existence and is not directed toward convicts (not quite so, of course, but we shall speak more about it below). And this is confirmed in Article 1 of the RF Penal Enforcement Code, which states that the goals of penal enforcement legislation include preventing the commission of new crimes by other persons, i.e. not only and not even so much by convicts, but by those who are outside the scope of FSIN. And there is no contradiction in this, because prevention on the part of the Federal Penitentiary Service consists in intimidating unstable citizens who are prone to illegal conduct. FSIN tacitly warns such people: "If you behave badly, you will end up with us".

As for the prevention of the commission of new crimes by convicts who are in correctional institutions, this is achieved by establishing severe, mainly punitive restrictions; it is contained in the RF Penal Enforcement Code and therefore it is legal; besides, it is determined by the specifics of the persons serving sentences, a significant part of whom are socially neglected citizens and are not ready to accept educational measures akin to those used at the kindergarten.

Nevertheless, the work on the reformation of convicted persons is being carried out, including, among other things, with the use of specific educational techniques and which, it seems, are not to be discussed in detail in the open press.

Prevention on the part of the penal system is of the greatest importance for those who leave its scope and, first of all, for those convicts who have served a sentence of imprisonment, and among them, first of all, for those who have served sentences for grave crimes. It is worth noting that the problem of social adaptation (not to mention social rehabilitation) of these persons to life outside correctional institutions is of great concern to law-abiding citizens, especially after the mass murders committed by such persons shortly after their release (for example, the murder of the entire family, including children, in Khakassia on August 5, 2021).

In this regard, the work of probation inspectorates is of great importance, since their employees, by virtue of their duties, know everything about the released person. Unfortunately, until recently, there has been no effective mechanism for interaction between probation inspectorates and those bodies, organizations and police officers in charge of which the former convict is. Under such circumstances, there exist considerable difficulties regarding preventive work with people whose views on normal life are far from normal.

As for the public, its role in the work of the Federal Penitentiary Service is minimal. This directly follows from the norms of the current legislation, which refers to clergymen and leaves representatives of the public behind (except for the execution of punishment in the form of restriction of freedom). 
Of course, there emerge many questions here.

First, today the implementation of prevention tasks is fraught with many difficulties, some of which seem, at least, intractable. It has always been difficult to attract even the most eager social activists with slogans without providing them with any tangible preferences, and it has become almost impossible in the conditions of capitalist economic management, where consumer interests are a priori in the first place.

Second, there is certainly an interest in this preventive work, especially on the eve of various election campaigns. In this regard, certain unexpected organizational difficulties arise when representatives of various political parties and organizations can begin to use preventive work as a means to obtain additional electoral points. There is a contradiction that will be aggravated - by its nature, prevention is an everyday and not very grateful work, which will turn into an efficient demonstration farce.

Third, along with the increase in the scope of prevention in the organizational structure of the law enforcement system, there will be an ever growing danger that representatives of the criminal environment, and more specifically, organized crime, will begin to penetrate into it under the guise of those most eager social activists.

\section{Improving prevention}

D.Yu. Yakovlev suggests the following measures to prevent crime.

1. Legislative consolidation of the crime prevention system: a) at preschool, school and other educational levels (by introducing the institute of curatorship, classroom guidance or mentoring); b) at the medical level (identification of any deviations in persons prone to deviant behavior); c) at the law enforcement level (prevention of misconduct among both youth and adults by participating in school meetings, meetings of residents of apartment buildings, meetings at district police stations, yard rounds).

2. Combating the sources of crime, drunkenness and drug addiction by eliminating the centers of production and distribution of illegal alcohol, drugs and psychotropic substances, identifying places where anti-social characters gather.

3. Conducting planned and unscheduled inspections of criminogenic residential zones (dormitories, communal apartments, barracks), where citizens lead an antisocial lifestyle.
4. Formation, development (restoration) of the system of freelance assistants to district police commissioners.

5. Joint formation of law enforcement-oriented public associations by internal affairs bodies and local governments [9].

\section{Prevention and new technologies}

E.Yu. Chuklina believes that modern crime prevention should be based on technological innovation. Modern technologies help to track all the movements of a person using a mobile phone or to establish the range of their interests by analyzing their web browsing history. At the same time, there are two main types of technological innovations: a) information technologies (so-called soft technologies); b) material technologies (hard technologies). According to E.Yu. Chuklina, situational crime prevention, on which her approach is based, includes technologies (hardware or materials) and software technologies (computer software, information systems). Accordingly, hard technologies designed to prevent the commission of a crime include: a) video surveillance cameras; b) metal detectors in schools, universities and crowded places; c) baggage inspection and personal inspection at airports and train stations; d) bulletproof cash windows in banks; e) security systems in homes and at enterprises.

The police use the following hard technologies: a) new weapons; b) new patrol vehicles with improved technologies; c) new means of protecting police officers.

Soft technologies comprise computer programs for the prevention of crimes, including: a) tools for assessing criminal threats; b) streaming information in police vehicles; c) notifying the police when there is an excessive crowd in one place; d) face recognition to identify wanted persons.

The United States uses federal programs with databases that systematize the places of crimes committed and at the same time assess personal characteristics of criminals.

There is a well-known idea about creating a system of remote control over crime using population chipping programs. Many countries have been following this path for quite a long time. For example, one cannot enter any EU member state without first submitting one's fingerprints.

It is difficult to say how far such programs will go. There are obvious moral and religious costs. There are great doubts about the possibilities of legal support for this path. (It would be necessary to either cancel or ignore the fun- 
damental international legal acts concerning the inviolability of the individual). At the same time, the increased dependence of situational crime prevention on soft and hard technologies will inevitably lead to increased dependence on forced surveillance and to the so-called forced control strategy [8].

We cannot say for sure what we will get in return. In any case, the opinions of science fiction writers on this issue do not look optimistic. The more control there is, the more opportunities for abuse for those who have access to control.

\section{Prevention and the public}

Prevention of offenses and crimes is impossible without public participation.

In Soviet times, the role of the public in this work was as great as it was underestimated. The decision to bring a young man to criminal responsibility was often preceded by a mandatory hearing on his conduct at a Komsomol meeting, a meeting of the labor collective, or a meeting of residents. If it was a question of a possible crime of a member of the CPSU, then the decision of this public association actually predetermined the future decision of the prosecutor and the judge. The same thing, only in an even more strictly regulated manner, concerned officers - the prosecutor could not even initiate a criminal case against the officer without the appropriate permission of the commander of the military unit. In turn, the decision of the commander of the unit was based on the decision of the officers' meeting. It is clear that such public meetings were feared no less than the prosecutor's office. But at the same time, the possibility of not bringing a person to criminal responsibility and, instead, transferring them to a public organization for re-education was widely used (the mechanisms of community courts and courts of honor were used).

Obviously, in modern Russian society, the majority of these non-governmental institutions cannot function. But this does not mean that the role of the public in the prevention of offenses and crimes has become less significant because of this. On the contrary, only thanks to the public, real prevention is possible. The public should be embedded into prevention.
The first and very good step in this direction was the adoption in 2014 of the Federal Law "On the participation of citizens in the protection of public order" [7]. It is important that this good step does not remain the only one.

\section{Conclusions}

1. It is blasphemy to engage in prevention while relying on punitive means of influence.

2. The public remains the most important element in the prevention system.

3. Public participation should be embedded into prevention (for example, as it is done in Article 11 of the Federal Law "On the fundamentals of the system for prevention of neglect and juvenile delinquency" [5], although in our opinion, there is a lot of formalism and little result in the work of commissions on juvenile affairs).

4. The main weapon in the hands of the subjects of prevention is legal education (it is hardly ever used nowadays).

5. Neither control, nor an acceptable level of crime, but the elimination of crime is the prime direction of prevention (at least in its modern sense).

Thus, the theory and practice of crime prevention are currently at variance with each other. On the one hand, the theoretical constructions of crime prevention are becoming more and more disconnected from reality. On the other hand, the legislation on prevention is not supported by scientific research and is developing according to its own rules, mostly political and populist (obviously, none of the legal norms in this area is supported by material resources, and therefore looks dead already at the stage of its adoption).

Practitioners of law enforcement agencies, including employees of the Federal Penitentiary Service, are not focused on crime prevention.

It turns out that there is a completely understandable, but no less paradoxical situation crime prevention seems to exist, but in fact it does not.

By the way, the Federal Law on Prevention was adopted in 2016. Five years have passed, and not a single amendment has been made to it. Is it because the law is so good? Or because no one is interested in it (no one needs it).

\section{REFERENCES}

1. Alekseev A.I., Gerasimov S.I., Sukharev A.Ya. Kriminologicheskaya profilaktika: teoriya, opyt, problem [Criminological prevention: theory, experience, problems]. Moscow: Norma, 2001. P. 13.

2. Kudryavtsev V.N., Karpets I.I., Korobeinikov B.V. (Eds.). Kurs sovetskoi kriminologii [Course on Soviet criminology]. Moscow: Yurid. lit., 1986. 352 p. P. 19.

3. On charitable activities and volunteerism: Federal Law no. 135-FZ of August 11, 1995. In: Sobranie zakonodatel'stva Rossiiskoi Federatsii [Collection of legislation of the Russian Federation]. 1995. No. 33. Article 3340. (In Russ.). 
4. About the concept of construction and development of the hardware and software complex "Safe City": Resolution of the Government of the Russian Federation no. 2446-r of December 3, 2014. In: Sobranie zakonodatel'stva Rossiiskoi Federatsii [Collection of legislation of the Russian Federation]. 2014. No. 50. Article 7220. (In Russ.).

5. On the fundamentals of the system for prevention of neglect and juvenile delinquency: Federal Law no. 120-FZ of June 24, 1999. In: Sobranie zakonodatel'stva Rossiiskoi Federatsii [Collection of legislation of the Russian Federation]. 1999. No. 26. Article 3177. (In Russ.).

6. On the fundamentals of the prevention system in the Russian Federation: Federal Law no. 182-FZ of June 23, 2016. In: Sobranie zakonodatel'stva Rossiiskoi Federatsii [Collection of legislation of the Russian Federation]. 2016. No. 26 (Part I). Article 3851. (In Russ.).

7. On the participation of citizens in the protection of public order: Federal Law no. 44-FZ of April 2, 2014. In: Sobranie zakonodatel'stva Rossiiskoi Federatsii [Collection of legislation of the Russian Federation]. 2014. No. 14. Article 1536. (In Russ.).

8. Chuklina E.Yu. Situational prevention measures in the Russian theory of crime prevention. Natsional'naya bezopasnost'=National Security, 2016, no. 3 (44), pp. 338-346. (In Russ.).

9. Yakovlev D.Yu. Crime prevention: to be or not to be. Rossiiskii sud'ya=Russian Judge, 2018, no. 9, pp. 37-41. (In Russ.). 10. Lin Shu-Ching. The strategies of situational crime prevention in drunk driving. Journal of Criminology, 2017, vol. 20, iss. 1, pp. 29-61.

\section{INFORMATION ABOUT THE AUTHOR}

IGOR' M. MATSKEVICH - Doctor of Sciences (Law), Professor, Honored Scientist of the Russian Federation, head of the Department of Criminology and Penal Law at Kutafin Moscow State Law University, Moscow, Russian Federation, professor at Lomonosov Moscow State University, Moscow, Russian Federation, president of the Union of Criminalists and Criminologists. ORCID: https://orcid.org/0000-0002-4270-1599, e-mail: mackevich2004@mail.ru 